MaPan : Jurnal Matematika dan Pembelajaran

p-ISSN: 2354-6883 ; e-ISSN: 2581-172X

Volume 8, No 1, June 2020 (103-113)

DOI: https://doi.org/10.24252/mapan.2020v8n1a8

\title{
STUDENTS THINKING PROCESS IN SOLVING THE PROBLEMS OF SOCIAL ARITHMETIC STORIES TEST BASED ON GENDER
}

\author{
Ai Siti Nurhayati1), Usman Aripin²) \\ 1,2IKIP Siliwangi \\ 1,2Jl. Terusan Jendral Sudirman, Cihami \\ E-mail: aisitinurhayati23@gmail.com²), usman.aripin@ikipsiliwangi.ac.id ${ }^{2}$
}

Received April 29, 2020; Revised May 17, 2020; Accepted June 10, 2020

\begin{abstract}
:
This study aims to find out how the thinking process of female and male students in solving problems analyzed using thinking type indicators according to Zuhri and Wing that divided into three, namely conceptual, semi-conceptual, and computational thinking processes. This research method used a qualitative descriptive study. The instrument in the study consisted of test questions given to 34 VII grade students in one of Junior High School in Cimahi. Based on the results, can be known about the conceptual thinking process only done by female students with a percentage of $11.8 \%$, the semi-conceptual thinking process of female students was $64.7 \%$ and $47 \%$ of male students, as for computational thinking process of female students was $23.5 \%$ and $53 \%$ male students. From the results of this study, it can be concluded that female students tend to think semi-conceptually while male students tend to think computationally.
\end{abstract}

Keywords: Thinking Proses, Social Arithmetic, Gender

\section{PROSES BERPIKIR SISWA SMP DALAM MENYELESAIKAN SOAL CERITA ARITMATIKA SOSIAL BERDASARKAN GENDER}

\begin{abstract}
Abstrak:
Penelitian ini bertujuan untuk mengetahui bagaimana proses berpikir siswa perempuan dan laki-laki dalam menyelesaikan masalah yang dianalisis menggunakan indikator jenis berpikir menurut Zuhri dan Wing yang dibagi menjadi tiga yaitu proses berpikir konseptual, semi-konseptual, dan komputasi. Metode penelitian ini berupa penelitian deskriptif kualitatif. Instrumen dalam penelitian berupa soal tes yang diberikan kepada 34 siswa kelas VII SMP di Kota Cimahi. Berdasarkan hasil penelitian yang telah dilakukan dapat diketahui bahwa proses berpikir konseptual hanya dilakukan siswa perempuan dengan persentase $11,8 \%$, proses berpikir semikonseptual siswa perempuan adalah $64,7 \%$ dan siswa laki-laki $47 \%$, sedangkan untuk proses berpikir komputasi siswa perempuan adalah $23,5 \%$ dan siswa laki-laki $53 \%$. Dari hasil penelitian tersebut dapat disimpulkan bahwa siswa perempuan cenderung berpikir secara semikonseptual, sedangkan siswa laki-laki cenderung berpikir secara komputasional.
\end{abstract}

Kata kunci: Proses Berpikir, Aritmatika Sosial, Gender 
How to Cite: Nurhayati, A. S., \& Aripin, U. (2020). Students Thinking Process in Solving the Problems of Social Arithmetic Stories Test Based on Gender. MaPan: Jurnal $\begin{array}{lll}\text { Matematika dan Pembelajaran, } & \text { 8(1), 103-113. }\end{array}$ https://doi.org/10.24252/mapan.2020v8n1a8.

\section{INTRODUCTION}

$\mathrm{I}$

$n$ this globalization era, of course, we are required to be able to compete in various fields that concern our lives. To be able to compete in this era of globalization, of course, we must have the knowledge needed in the fields of education, social, economics, and culture. One of the knowledge that must be possessed is mathematical knowledge. Mathematics is one of the sciences most often used by humans to help and facilitate the work that is being done. Also, according to Nuriadin \& Perbowo (2013), mathematics can also support one's career.

The importance of mathematics is in accordance with the opinion of Hendriana (2014), which states that mathematics is a part that can be connected with real life, which is very useful for everyday life. Various problems of daily life can be modelled in mathematics and then sought solutions based on the rules contained in mathematics. For example, in economic activities, we often find discounts at shopping centres, prices of products, or food that rise after getting taxes or calculate losses and profits derived from sales. To be able to know these things, of course, it is necessary to have an understanding of solving mathematical problems in economic activities. In learning mathematics, one of the chapters that can facilitate us in economic activities, one of which is about social arithmetic.

Social arithmetic is one of the chapters studied in class VII of Junior High School. Social arithmetic is a mathematical operation used by society, usually in the economic field. The discussions learned in social arithmetic include the sale and purchase, profit and loss, single interest, discounts, taxes, gross, net, and tare. Abubakar (2016) also stated that social arithmetic is one of the chapters in school mathematics, which is very directly related to daily life such as in buying and selling activities in the community where profit and loss is one of the concepts taught in social arithmetic learning especially in junior high school.

In the matter of social arithmetic, many problems are presented to test students' abilities. Usually, the problem presented is a problem in the form of a story. Story problems, according Herto, Rasyid, \& Sulasteri (2018), mathematical problems related to issues in daily life that are sought by using 
mathematical sentences. Besides that, according to Rahmawati \& Nur Azizah (2018), problem story is one form of the question that presents problems related to everyday life in the form of stories. By giving mathematical problems in everyday life, it will undoubtedly make it easier for students to understand the concepts they have learned. Understanding the concept by presenting mathematical problems in daily life is in accordance with the results of Carreira, S's research (Hendriana, 2012), which says that the application of mathematical problems in real phenomena provides its conditions to produce meaning and understanding in these mathematical concepts.

However, based on research conducted by Ningrum (2013) states that 9 out of 10 students can solve problem stories that are still lacking, the reason is caused by several factors, namely students making mistakes in aspects of language and aspects of prerequisites. Research conducted by Wulandari \& Hidayat (2019) which states that students' understanding ability is still weak, especially in solving social arithmetic story problems. Likewise, with research conducted by Pranita, Marsitin, \& Suwanti (2019) states that students' abilities in carrying out plans are still lacking so that it becomes a problem in solving problems. In addition to the lack of student planning skills, students also have difficulty operating numbers. Difficulties in number operations are in line with the opinion of Nursalam (2016), which states that the most problem faced by students is to operate fractions, this is caused by the lack of students' ability to operate numbers. The lack of these abilities has resulted in various ways to solve story problems. Then this is a problem that arises from students' thought processes.

The thinking process is a way taken by someone in solving a problem. However, the problems above are still general, where we do not know how male and female students do the thinking process. Though the process of thinking of one person with another certainly varies. Based on research conducted by Wahyuningsih, Sani, \& Sudia (2019) states that students thinking processes in solving a problem have different characteristics seen from cognitive and gender styles. The study is also in line with research conducted by Yuliana \& Winarto (2019), which states that there are significant differences in self-efficacy assessments and problem-solving abilities between male and female students.

Also, according to Dagun's opinion (Pramesti, 2014), which states that men and women have their respective advantages, men excel in the field of vision while women excel in the verbal field. Then according to Krutetzki (Pramesti, 2014) states that in thinking, female students are superior in accuracy, 
accuracy, accuracy, and equality, in contrast to male students who tend to be less thorough, in a hurry, and tend to accomplish things shortly. Therefore it is necessary to have a study that describes how the thinking process of male and female students in solving social arithmetic problems. So in this study we will describe how the thinking process is done by male and female students in solving social arithmetic problems.

\section{RESEARCH METHOD}

This type of research is a type of qualitative descriptive study that aims to describe how the differences in the thinking processes of male and female students in solving social arithmetic story problems. According to Abdurahman (Sari \& Aripin, 2018), descriptive research aims to describe precisely the nature of individuals, situations, symptoms, or certain groups. Qualitative research, according to Moleong (Alifah \& Aripin, 2018), is research that aims to understand phenomena experienced by research subjects relating to behavior, perception, actions, etc. thoroughly by describing in certain scientific contexts and using various scientific methods.

The subjects in this study were 34 students of class VIII SMP in Cimahi City who were randomly selected, consisting of 17 female students and 17 male students. The instrument in this study was a social arithmetic test consisting of six-story test questions. Data collection techniques used are providing social arithmetic tests to the subjects studied with an allocation of 80 minutes.

The arithmetic test data are then analyzed based on indicators that influence the type of thought process, according to Zuhri and Wing (Lestariningsih, Nurhayati, \& Cicinidia, 2020), which are divided into three namely conceptual, semi-conceptual, and computational. To describe the types of students' thought processes, according to Nugroho (Lestariningsih, Nurhayati, \& Cicinidia, 2020), there are specific rules, namely:

1. Subjects are said to have certain types of thought processes if the indicators of this type of thought process are met more than others.

2. If the subject does not meet criteria one, then the type of subject thought process cannot be classified.

It is, therefore, based on indicators that meet the types of conceptual, semi-conceptual, and computational thinking processes. Then the following is a table of types of thought processes that adapt thinking process indicators according to Zuhri and Wing (Lestariningsih, Nurhayati, \& Cicinidia, 2020). 
Table 1. Indicators of Types of Thinking Processes

\begin{tabular}{|c|c|c|}
\hline $\begin{array}{l}\text { Types of Conceptual } \\
\text { Thinking Processes }\end{array}$ & $\begin{array}{c}\text { Types of Semi } \\
\text { Conceptual Thinking } \\
\text { Processes }\end{array}$ & $\begin{array}{c}\text { Types of } \\
\text { Computational } \\
\text { Thinking Processes }\end{array}$ \\
\hline $\begin{array}{l}\text { 1. Able to state aspects } \\
\text { that are known in } \\
\text { the problem with } \\
\text { their language or } \\
\text { change in } \\
\text { mathematical in } \\
\text { sentences. }\end{array}$ & $\begin{array}{l}\text { 1. Less able to state } \\
\text { aspects that are } \\
\text { known in the } \\
\text { problem with their } \\
\text { language or change } \\
\text { in mathematical } \\
\text { sentences. }\end{array}$ & $\begin{array}{l}\text { 1. Unable to state } \\
\text { aspects known in } \\
\text { the problem in their } \\
\text { language or change } \\
\text { in mathematical } \\
\text { sentences. }\end{array}$ \\
\hline $\begin{array}{l}\text { 2. Able to state aspects } \\
\text { that are asked in a } \\
\text { problem with their } \\
\text { language or change } \\
\text { in mathematical } \\
\text { sentences. }\end{array}$ & $\begin{array}{l}\text { 2. Less able to state } \\
\text { the aspects that are } \\
\text { asked in the } \\
\text { problem with their } \\
\text { language or change } \\
\text { in mathematical } \\
\text { sentences. }\end{array}$ & $\begin{array}{l}\text { 2. Unable to state the } \\
\text { aspects that are } \\
\text { asked in the } \\
\text { problem in their } \\
\text { language or change } \\
\text { in mathematical } \\
\text { sentences }\end{array}$ \\
\hline $\begin{array}{l}\text { 3. Can make a } \\
\text { complete settlement } \\
\text { plan }\end{array}$ & $\begin{array}{l}\text { 3. Can make a } \\
\text { complete plan but it } \\
\text { is incomplete }\end{array}$ & $\begin{array}{l}\text { 3. Cannot make a } \\
\text { settlement plan }\end{array}$ \\
\hline $\begin{array}{l}\text { 4. Able to state the } \\
\text { steps taken in } \\
\text { solving problems } \\
\text { using concepts that } \\
\text { have been learned }\end{array}$ & $\begin{array}{l}\text { 4. Less able to state } \\
\text { the steps taken in } \\
\text { solving problems } \\
\text { using concepts that } \\
\text { have been learned }\end{array}$ & $\begin{array}{l}\text { 4. Unable to state the } \\
\text { steps taken in } \\
\text { solving problems } \\
\text { using concepts that } \\
\text { have been learned }\end{array}$ \\
\hline $\begin{array}{l}\text { 5. Able to correct } \\
\text { mistakes in answers }\end{array}$ & $\begin{array}{l}\text { 5. Less able to correct } \\
\text { the wrong answers }\end{array}$ & $\begin{array}{l}\text { 5. Unable to correct } \\
\text { the wrong answers }\end{array}$ \\
\hline
\end{tabular}

\section{RESULTS AND DISCUSSION}

According to Aripin \& Purwasih (2017), mathematical thinking is defined as the application of techniques, concepts, or mathematical processes implicitly and explicitly. While the thought process, according to Pramesti (2014), is a cognitive activity that occurs in a person's mental or mind and acts internally. According to Aini (2017), the thought process is a mental activity that is used to help formulate or solve problems. So the process of thinking is cognitive activity to complete actions, determine, and complete discussion.

Conceptual thinking is the process of thinking in completing tasks using existing concepts. The semi-conceptual thinking process is the process of thinking in completing a task by using a concept that is owned combined with 
intuition. The computational thinking process is the process of thinking in completing tasks without using concepts but relying on intuition (Lestariningsih, Nurhayati, \& Cicinidia, 2020).

Based on the results of research that has been carried out, the following is the percentage of the thinking process of female and male students.

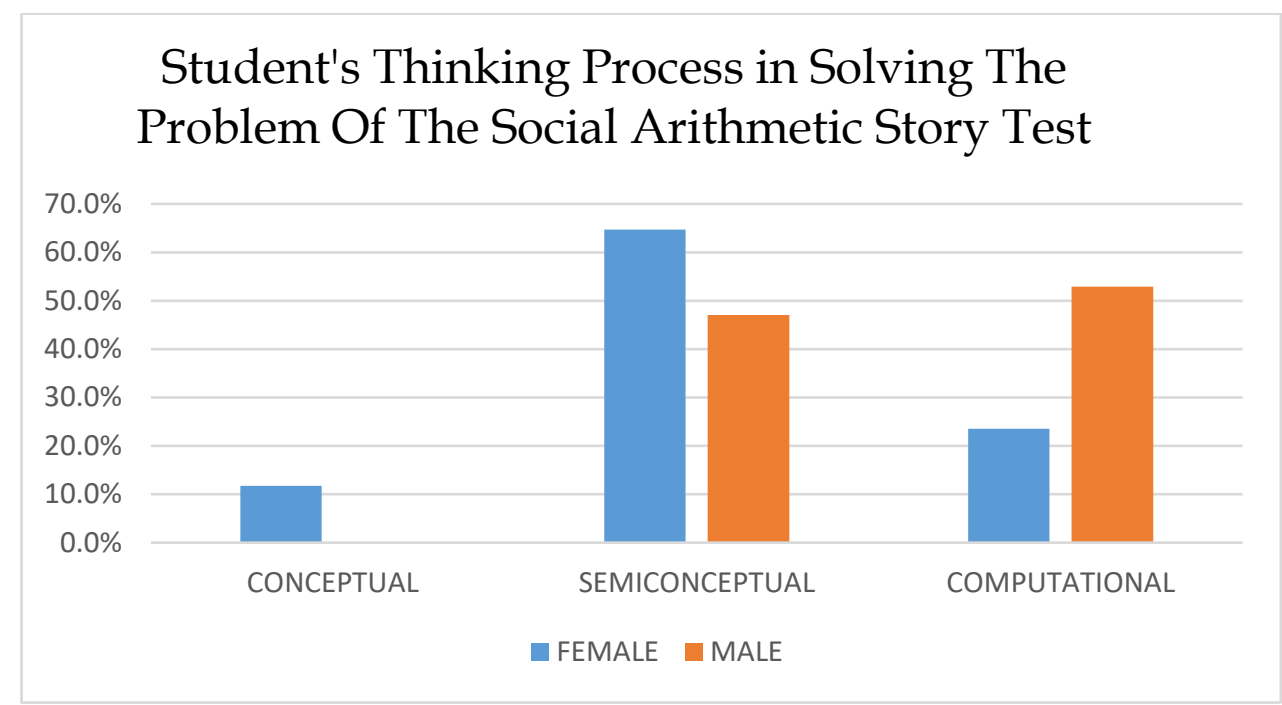

Figure 1. Graph of Students' Thinking Process

Based on the graph above, it can be seen that students who have a conceptual thinking process are only female students, with a percentage of $11.8 \%$ of the total female students. Semi conceptual thinking process is owned by female students, with a percentage of $64.7 \%$ of the total female students and male students, with a percentage of $47 \%$ of the total male students. While female students own the computational thinking process, with a percentage of $23.5 \%$ female students and male students with a percentage of $53 \%$ of the total male students researched.

So from this data can be seen in the conceptual thinking process that is only done by 2 female students. For the semi conceptual thought process is carried out by 11 female students and 8 male students. Then for the computational thinking process carried out by 4 female students and 9 male students. The following figures are the results of the answers of students who have conceptual, semi conceptual and computational thought processes as well as discussions of thought processes. 


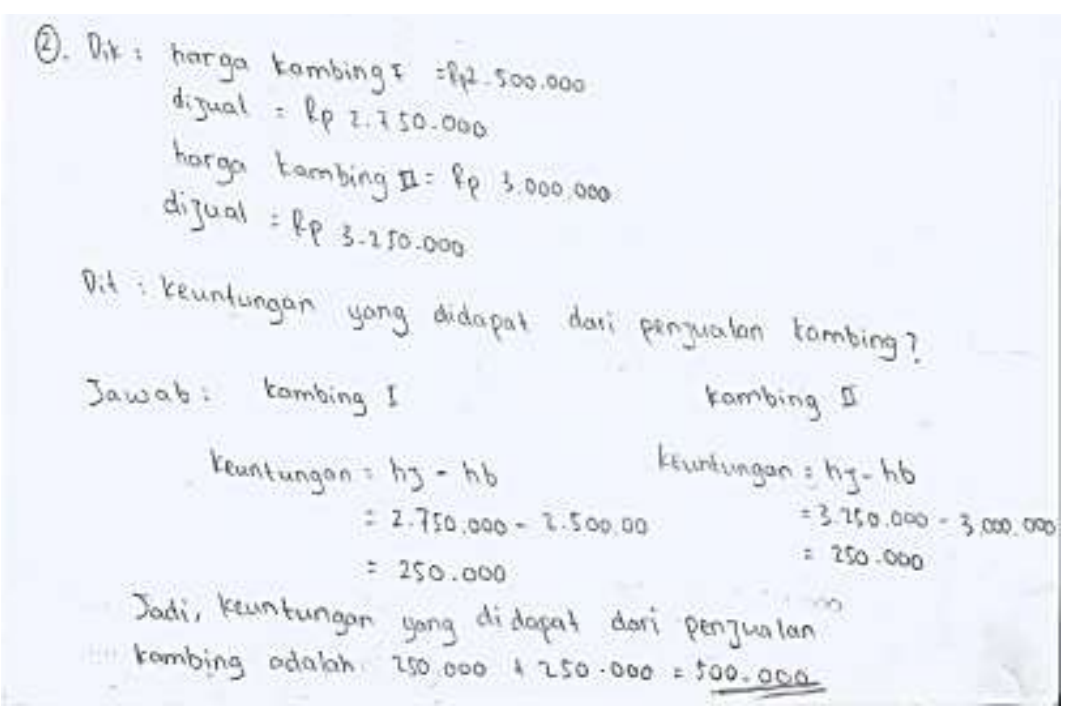

Figure 2. Answers from Subjects with Conceptual Thinking Process Skills

Based on the results of students' answers above, students can write what they know and also ask, they can make plans to solve problems, take steps to solve problems using concepts that have been learned and make conclusions correctly. This is consistent with the thought process indicator described earlier. So from the answers above, it can be concluded that students have a conceptual thinking process. The conceptual thinking process, according to Febriliyani \& Ratu (2018), is the way a person thinks in solving problems by using concepts that have been studied previously.

Likewise in research conducted by Ramli \& Hidayat (2019), he stated that students with conceptual thinking processes could say what is known and asked to use their language or change mathematical sentences, make plans to complete the steps taken from methods using this concept has been studied and can state conclusions at the end of the settlement.

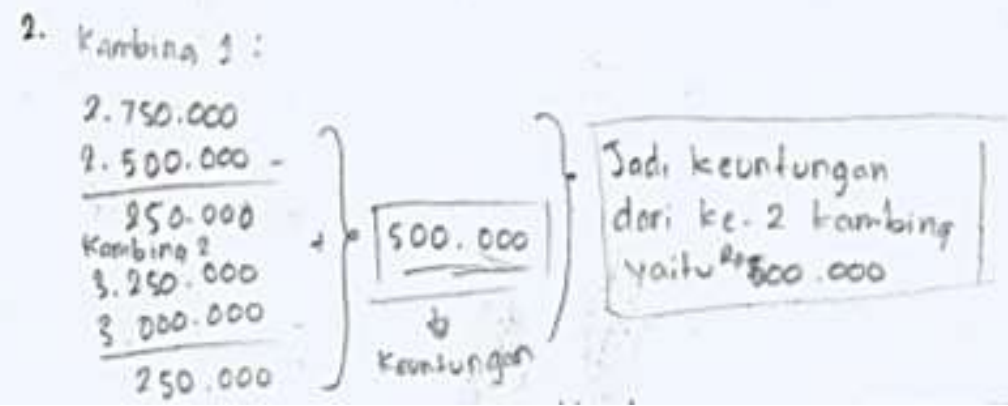

Figure 3. Answers from Female Subjects with A Semi Conceptual Thinking Process 

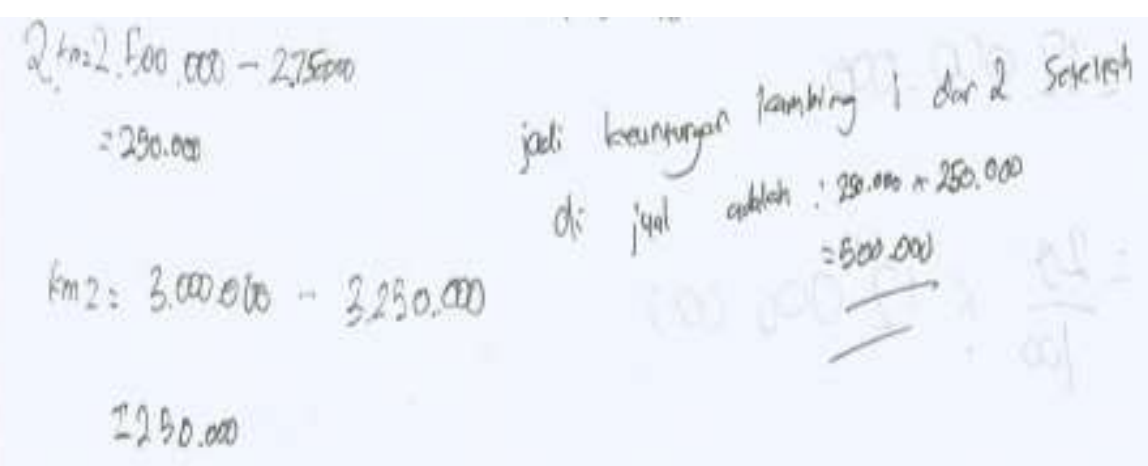

Figure 4. Answers from Male Subjects with A Semi Conceptual Thinking Process

From the two answers of female and male students, it appears that they did not write down what was known and asked, but could still make plans to solve the problem even though it was incomplete, and incomplete in making conclusions. So when viewed from indicators of the thinking process, both students tend to think semi conceptual. According to Febriliyani \& Ratu (2018), the process of semi conceptual thinking is a way of thinking in solving problems using concepts. Still, the concept is incomplete, so the solution is mixed with intuition.

This is also consistent with research conducted by Ramli \& Hidayat (2019) in which students with semi conceptual thinking processes have characteristics that are less able to express in their language what is known and asked in a problem, less able to make plans completed with steps taken from planning and cannot state conclusions at the end of the settlement.

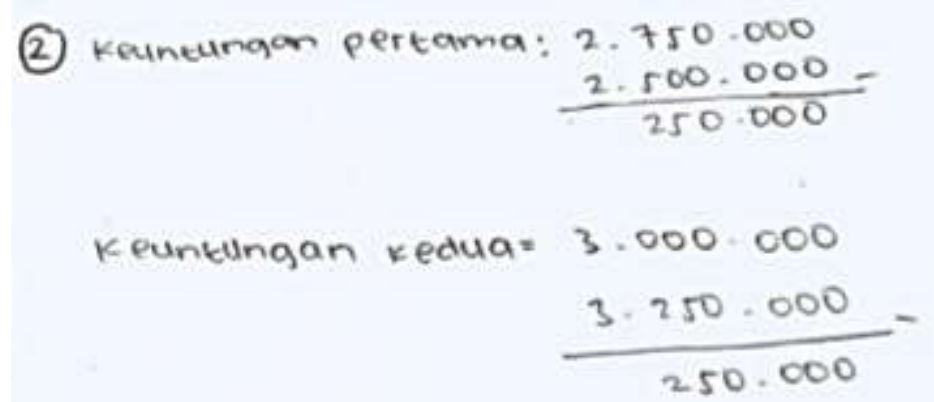

Figure 5. Answers from Female Subjects with Computational Thinking Processes 


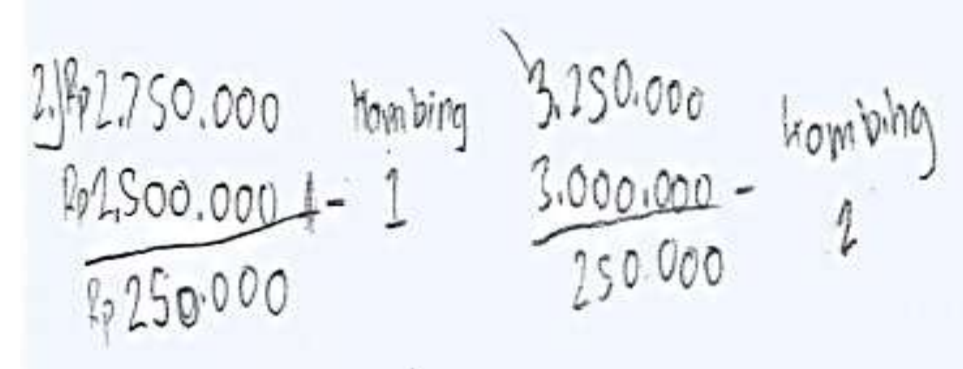

Figure 6. Answers from Male Subjects with Computational Thinking Processes

From the two answers of female and male students with the above process, if seen from the results of the answers and indicators of the thinking process, it appears that they both did not write what was known and asked, did not make a complete settlement plan, and could not make conclusions to answer what was asked. Then both students tend to have computational thinking processes.

Based on research conducted by Ramli \& Hidayat (2019), students with computational thinking processes also have the characteristic of not being able to make conclusions at the end of completion. That is because students with computational thinking processes tend to think according to their thoughts, so they lack understanding even do not know what is asked in the problem presented. This is in line with the opinion of Febriliyani \& Ratu (2018), which states that the process of computational thinking is a way of thinking in solving problems that do not use concepts but use their intuition.

\section{CONCLUSION}

Based on the results of research that has been done, it turns out that the thinking process of male and female students is very diverse. The process of thinking of female students consists of conceptual thinking processes with a percentage of $11.8 \%$, semi-conceptual $64.7 \%$, and comparative $23.5 \%$. The thinking process of male students consists of semi-conceptual thinking processes, with a percentage of $47 \%$ and computational $53 \%$. Thus, the thinking process of female students tends to be semi-conceptual, while male students tend to be computational. 


\section{REFERENCES}

Abubakar, W. (2016). Analytical problem solving skills at social arithmatic in project based learning in grade 3 SMP Islam Athirah Bukit Baruga. Jurnal Daya Matematis, 4(3), 380-392. https://doi.org./10. 26858/jds.v4i3.2930.

Aini, K. N. (2017). Proses berpikir mahasiswa laki-laki dan perempuan dengan gaya kognitif field indefendent dalam memecahkan masalah. Inspiramatika, 3(1), 16-23. Retrieved from http:/ / e-jurnal.unisda.ac.id/.

Alifah, N., \& Aripin, U. (2018). Proses berpikir siswa SMP dalam memecahkan masalah matematika ditinjau dari gaya kognitif field defendent dan field indefendet. JPMI, 1(4), 505-512. http://doi.org/10.22460/jpmi. v1i4/p505-512.

Aripin, U., \& Purwasih, R. (2017). Penerapan pembelajaran berbasis alternative solutions worksheet untuk meningkatkan kemampuan berfikir kreatif matematik. Aksioma: Jurnal Pendidikan Matematika, 6(2), 225-233. https:/ / doi.org/10.24127/ajpm.v6i2.989.

Febriliyani, A., \& Ratu, N. (2018). Proses berpikir siswa dalam menyelesaikan masalah barisan dan deret aritmatika. Math Didactic, 4(3), 180-189. https: // doi.org/10.33654/math.v4i3.111.

Hendriana, H. (2012). Pembelajaran matematika humanis dengan metaphorical thingking untuk meningkatkan kepercayaan diri siswa. Infinity Jurnal Ilmiah Program Studi Matematika STKIP Siliwangi Bandung, 1(1), 90-103. https://doi.org/10.22460/inf.103.

Hendriana, H. (2014). Membangun kepercayaan diri siswa melalui pembelajaran matematika humanis. Jurnal Pengajaran MIPA, 19(1), 52-60. http:// doi.org/10.18269/jpmipa.v19i1.424.

Herto, Rasyid, M. R., \& Sulasteri, S. (2018). Peningkatan kemampuan menyelesaikan masalah soal cerita koneksi matematik melalui model pembelajaran learning cycle 5E. Lentera Pendidikan: Jurnal Ilmu Trabiyah dan Keguruan, 21(1), 73-83. https:/ / doi.org/10. 24252/lp.2018v21n1i7.

Lestariningsih, Nurhayati, E., \& Cicinidia. (2020). Jenis proses berpikir peserta didik dalam menyelesaikan soal literasi matematis. Musharafa:Jurnal Pendidikan Matematika, 9(1), 83-94. https://doi.org/10/ 31980/mosharafa. v9.1.601.

Ningrum, L. S. (2013). Analisis kemampuan siswa menyelesaikan soal matematika dalam benetuk cerita pokok bahasan barisan dan deret pada siswa kelas XII SMA Al-Islam 3 Surakarta (Universitas Muhammadiyah Surakarta). Retrieved from http:// publikasiilmiah.ums.ac.id.

Nuriadin, I., \& Perbowo, K. S. (2013). Analisis korelasi kemampuan berpikir kreatif matematik terhadap hasil belajar matematika peserta didik SMP Negeri 3 Lurangung Kuningan Jawa Barat. Infinity Jurnal Ilmiah Program Studi Matematika STKIP Siliwangi Bandung, 2(1), 65-74. https:/ / doi.org/ https://doi.org/10.22460/infinity.v2i1.p65-74. 
Nursalam. (2016). Diagnostik kesulitan belajar matematika: studi pada siswa SD/MI di Kota Makasar. Lentera Pendidikan: Jurnal Ilmu Trabiyah dan Keguruan, 19(1), 1-15. https:// doi.org/10.24252/lp. 2016v19n1a1.

Pramesti, R. D. (2014). Proses Berpikir siswa dalam menyelesaikan soal cerita tentang keliling dan luas persegi panjang ditinjau dari gender. Jurnal Ilmiah Pendidikan Matematika, 3(3), 189-194 Retrieved from https:// jurnalmahasiswa.unesa.ac.id/index.php/mathedunesa/article/view/1 $2845 / 11832$.

Pranita, I., Marsitin, R., \& Suwanti, V. (2019). Analisis kemampuan problem solving dalam menyelesaikan soal aritmatika sosial. Senastek Unikama, 2, 155-162. Retrieved from https:// conference.unikama.ac.id/artikel/.

Rahmawati, R., \& Nur Azizah, I. (2018). Desain didaktis berbasis model inkuiri untuk mengembangkan kemampuan pemecahan masalah matematis. MaPan, 6(2), 138-147. https://doi.org/10.24252/mapan. 2018v6n2a1.

Ramli, A., \& Hidayat, E. (2019). Kemampuan dan proses berpikir reflektif matematika peserta didik melalui penerapan model pembelajaran treffinger. Prosiding Seminar Nasional \& Call For Paper, 692-790. Tasikmalaya. Retrieved from http://jurnal.unsil.ac.id/index.php/ sncp/article/view/1114.

Sari, A. R., \& Aripin, U. (2018). Analisis kesalahan siswa dalam menyelesaikan soal cerita bangun datar segiempat ditinjau dari kemampuan pemecahan masalah matematik untuk siswa kelas VII. JPMI, 1(6), 1135-1142. https:/ / doi.org/10.22460/jpmi. v1i6.p1135-1142.

Wahyuningsih, S., Sani, A., \& Sudia, M. (2019). Analisis proses berpikir siswa smp dalam memecahkan masalah matematik ditinjau dari gaya kognitif dan gender. Jurnal Pendidikan Belajar Matematika, 4(1), 121-132. https:/ / doi.org/10.33772/jpbm.v4i1.7171.

Wulandari, T., \& Hidayat, N. (2019). Analisis kemampuan pemahaman matematis siswa kelas VIII SMP negeri karawang barat dalam menyelesaikan soal cerita dengan materi aritmatika sosial. Prosiding Seminar Nasional Matematika dan Pendidikan Matematika, 1078-1087. Retrieved from https://journal.unsika.ac.id/index.php/sesiomadika/ article/view/2470.

Yuliana, W., \& Winarto, W. (2019). Penilaian self efficacy dan kemampuan pemecahan masalah matematika berdasarkan perpektif gender. MaPan: Jurnal Pendidikan Matematika dan Pembalajaran, 7(1), 41-60. https:// doi.org/https://doi.org/10.24252/mapan.2019v7n1a4. 